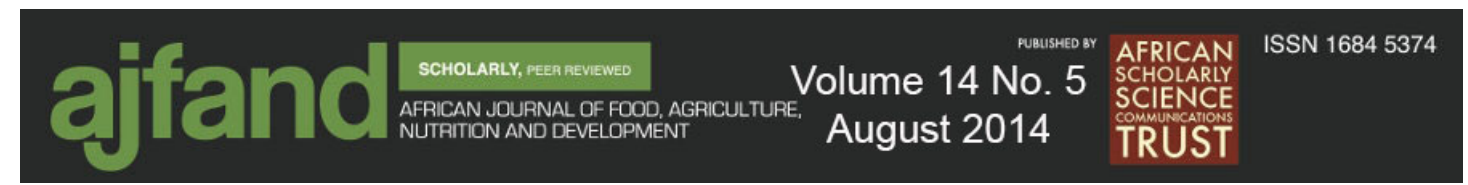

\title{
PROTEIN AND IRON COMPOSITION OF COWPEA LEAVES: AN EVALUATION OF SIX COWPEA VARIETIES GROWN IN EASTERN AFRICA
}

Okonya JS*1,2 and BL Maass ${ }^{1,3}$

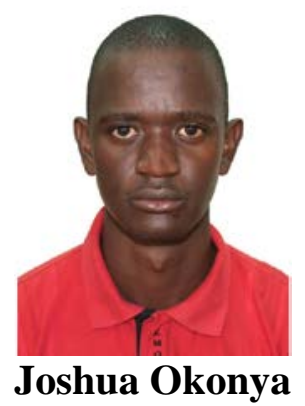

*Corresponding author email: j.okonya@cgiar.org

${ }^{1}$ Institute of Agronomy in the Tropics, Georg-August-Universität, Grisebachstr. 6, 37077 Götttingen, Germany

${ }^{2}$ Global Program of Integrated Crop and Systems Research, International Potato Center (CIP), P.O. Box 22274, Kampala, Uganda

${ }^{3}$ Tropical Forages Program, International Center for Tropical Agriculture (CIAT), P.O. Box 823-00621, Nairobi, Kenya. 


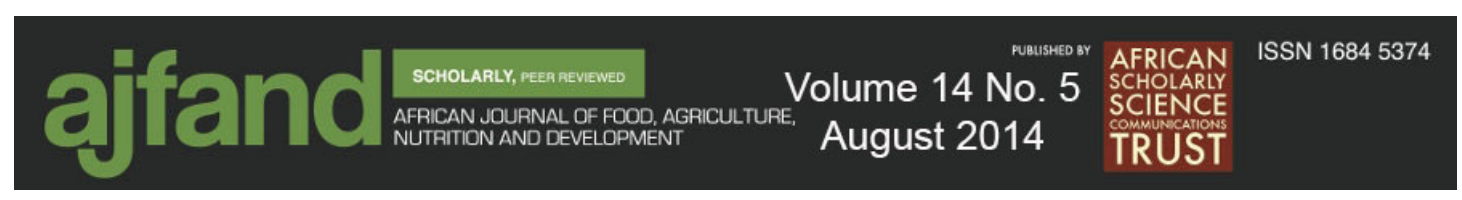

\begin{abstract}
Mineral element, protein-energy and micronutrient deficiencies are primary public health concerns in Eastern and Southern Africa. Promoting the consumption of traditional vegetables such as leaves of cowpea Vigna unguiculata (L.) Walp could provide cheap sources of protein, micronutrients and mineral elements that can improve the nutritional status of resource-poor subsistence farmers. This study evaluated leaves of two Ugandan cowpea landraces (Icirikukwai and Ebelat) in comparison to four Tanzanian varieties (UG-CP-9, Dakawa, Ex-Iseke and IT 93K2045-29) for leaf crude protein and iron contents. Tender vegetable leaves of landraces, four cowpea varieties and all possible 2-way, 3-way and 4-way combinations were harvested from three trial sites in the villages of Serere, Kikota and Kogili in eastern Uganda. Near Infrared Spectrometry (NIRS) was used to determine the crude protein content and iron concentration of open-air dried leaf samples. ANOVA for the leaf crude protein content and iron concentration data was done using the GLM procedure of SYSTAT. Leaf crude protein of Icirikukwai and Ebelat was 33.0 and $31.3 \%$, while iron concentration was 332.8 and $379.4 \mu \mathrm{g} / \mathrm{g}$, respectively. Leaf crude protein for the individual varieties was highest (31.84 \%) in UG-CP-9 leaves and lowest (28.02\%) in Ex-Iseke variety. Leaf crude protein for 2way, 3-way and 4-way mixtures was 30.99, 29.98 and 30.32\%, respectively. Leaves from Dakawa variety had the highest iron concentration $(349.1 \mu \mathrm{g} / \mathrm{g})$ of the four Tanzanian varieties tested. The mixture involving leaves from all the four varieties had the highest iron concentration values of $266.1 \mu \mathrm{g} / \mathrm{g}$ while 2-way mixtures gave the lowest iron concentration of $253.2 \mu \mathrm{g} / \mathrm{g}$. Compared to the tested varieties and their mixtures, iron concentration of landraces was not significantly higher. The protein content varied significantly across all the treatments and sites and was relatively high for a plant source. In addition, cowpea leaves are available as food throughout the cropping season and, thus, can be used for improved food security. These benefits, thereby, make cowpea leaves an indispensable tool to improve the nutritional status of resource-poor subsistence farmers in countries where cowpea is grown.
\end{abstract}

Key words: Vigna unguiculata, nutritional quality, leafy vegetables 


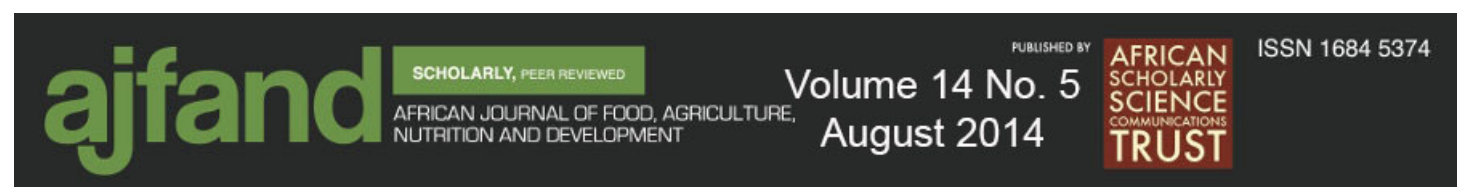

\section{INTRODUCTION}

Protein-energy, micronutrient and mineral element malnutrition are primary public health concerns in Eastern and Southern Africa. Results from the most recent comprehensive Uganda demographic and health survey conducted in 2011 indicate that $33 \%$ of the children under the age of five are stunted while $12 \%$ of the women are undernourished. The same survey also showed that up to $69 \%$ of the children (9-11 years), $48.4 \%$ of women and $50.2 \%$ of the men in Uganda are anaemic with an overall national prevalence rate at 23\%. Thirty six percent of the women (15-49 years) and $38 \%$ of children (6-59 months) tested were found to be vitamin A deficient [1]. Although there are many remedies to reducing anaemia and protein-energy malnutrition, adequate consumption of traditional green leafy vegetables, which are rich not only in protein but also micronutrients and mineral elements, offer a chance to reduce this high prevalence.

Traditional leafy vegetables are rich in proteins, vitamins A, B and C, as well as minerals like iron and calcium, making them an indispensable tool when it comes to reducing the prevalence of malnutrition, especially among resource-constrained rural and urban households [2, 3]. In addition, leafy vegetables are consumed by both lowincome and high-income groups, making this dietary diversification approach to be ideal $[4,5]$. The other advantage of this intervention of promoting consumption of traditional vegetables is that, these leafy vegetables are present in most home gardens, can grow in marginal environments and sometimes as weeds. What makes cowpea a superior candidate among other leafy vegetables is that minerals like calcium and iron in its leaves are not bound to phytic acid and are more bioavailable than those in cowpea seeds [6]. Since leaves are produced earlier and in bigger quantities than the seeds, the protein output from the leaves is said to be 15 times that of cowpea seeds and contains more essential amino acids [3, 7].

The most important traditional vegetables in sub-Saharan Africa include cowpea leaves (Vigna unguiculata (L.) Walp.), Nakati leaves (Solanum aethiopicum L.), Amaranth (Amaranthus spp.), African night shade (Solanum spp.), pumpkin leaves (Curcubita spp.) and African spider-flower (Cleome gynandra (L.) Briq.) [2, 5, $8,9,10]$. Among the top leafy vegetables consumed in many parts of sub-Saharan Africa, cowpea leaves rank third or fourth in terms of quantity consumed [6,9]. In Uganda, cowpea leaves are more popular than seeds especially in the Eastern and Northern regions and to a lesser extent in the Central region where they are traditionally part of a daily meal [personal observation].

The environment in which the cowpea is grown, the variety and stage of leaf harvest have also been observed to influence cowpea leaf protein content [11, 12]. Sun-drying prior to cooking, addition of crude sodium carbonate salt in the cooking water and long cooking time reduce the amount of available nutrients like vitamin $\mathrm{C}$ in these leafy vegetables $[6,8,13]$. It is important to note that besides quantity consumed, preparation and processing methods/procedures affect the nutrition quality of these leafy vegetables. 


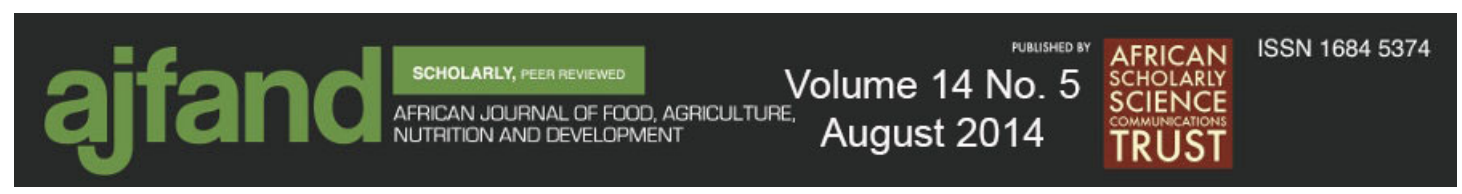

Cowpea leaf protein values evaluated in Tanzania varied from 29.4 to $33.1 \%$ for 23 varieties [12] and 25.0 to $34.4 \%$ for five varieties [14]. In Malawi, cowpea leaf protein content (dry weight basis) for 13 varieties varied from 35.0 to $43.1 \%$ [15]. In the 561 cowpea leaf samples collected from ten accessions and about ten landraces in Uganda and Tanzania, crude protein contents of 21.5 to $40.3 \%$ were recorded [16]. The iron concentration and $\beta$-carotene content in the same 561 samples ranged from 140.5 to $3994.7 \mu \mathrm{g} / \mathrm{g}$ and 4.1 to $30.5 \mathrm{mg} / 100 \mathrm{~g}$, respectively. Contents of up to 18.7 $\mathrm{mg}$ of iron, $0.547 \mathrm{mg}$ of zinc, and $4.45 \mathrm{mg}$ of beta carotene per $100 \mathrm{~g}$ of edible portion of freeze-dried raw cowpea leaves in the three districts of Kongwa, Singida and Arumeru, Tanzania have been reported [12].

Despite their contribution to household food security and poverty eradication, traditional vegetables have been neglected in many research and development programs of both international and national research institutions [12, 17]. There is, therefore, need to breed or improve dual purpose cowpea varieties for higher leaf yields since cowpea leaves are not only nutritious but cowpea leaf dishes form an important part of the diet in more than 18 countries in Africa and seven countries in Asia and the Pacific [3]. For instance, the average daily consumption of leafy vegetables per person in Uganda during the rainy season ranges from about $12 \mathrm{~g}$ in urban areas to $160 \mathrm{~g}$ in rural areas indicating that, though widely consumed in most parts of Uganda, not enough quantity is eaten to meet the nutritional requirements of the body [10].

Cowpea leaves are also appreciated by both rural and urban dwellers and could increase cash incomes of especially women who grow them both for home consumption and for sale in local markets $[4,18]$. The contribution of cowpea as a leafy vegetable to reducing poverty and malnutrition among the smallholder farmers and urban poor households, who cannot afford other nutrient-rich (protein, vitamin A, calcium and iron) foods like meat or fish, cannot be ignored if maximum impact of the crop is to be realized.

This study evaluates the two commonly grown Ugandan cowpea landraces in comparison to five promising dual purpose varieties from the World Vegetable Center (AVRDC) for leaf protein content and iron concentration. Since cowpea is often grown in mixtures, corresponding variety mixtures were also evaluated across three environments in Uganda; cowpea leaf and grain yield results of this investigation have been presented elsewhere [19].

\section{MATERIALS AND METHODS}

\section{Collection of Plant Materials}

The leaves were collected during the months of June and July 2008 from experimental plots at three sites of Serere, Soroti district (033'26'48.0' 'E, 01'32'22.6' 'N, $1140 \mathrm{~m}$

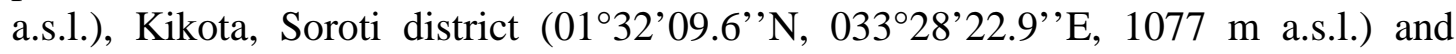

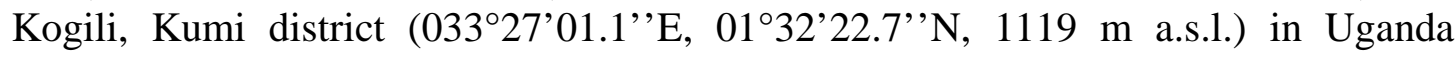




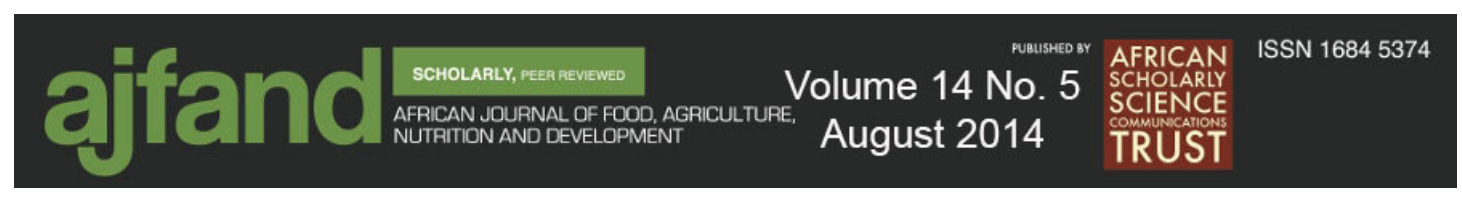

(Figure 1). Fully opened trifoliate, tender leaves suitable for human consumption from four dual-purpose cowpea varieties (UG-CP-9, Dakawa, Ex-Iseke and IT 93K-204529) and their corresponding 2-way, 3-way and 4-way mixtures (Table 1) were handpicked at six weeks after planting. After harvest, leaf samples were open-air dried under shade in net bags (320 x $440 \mathrm{~mm}$ ) for 1-2 weeks. The soils in the experimental plots were slightly to moderately acidic with low to deficient soil fertility. Details of soil analysis and crop management have been described elsewhere [19].

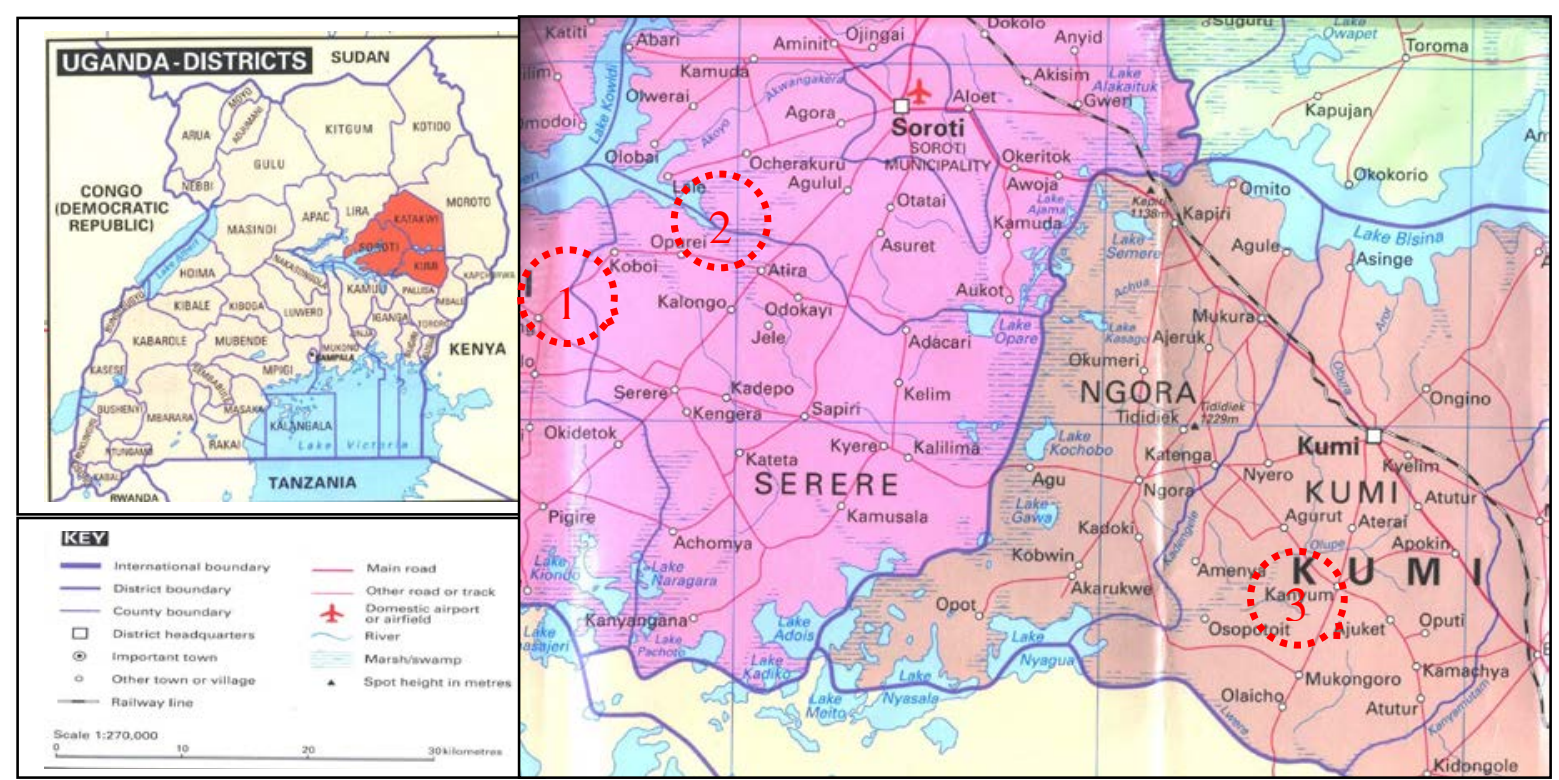

Figure 1: Location of trial sites on station at the National Semi Arid Resources Research Institute (NaSARRI), Serere (1), and on farm in Kikota village (2), and Kogili village (3), in Soroti and Kumi districts, Uganda.

\section{Infrared Spectrometry (NIRS)}

Dried cowpea leaf samples from the second leaf harvest of each trial were taken to the University of Götttingen, Germany, where they were milled through a $1 \mathrm{~mm}$ sieve to get a fine powder using a Culatti micro hammer mill (Type DFH 48). The leaf powder was put into cuvettes and scanned using a FOSS 6500 NIRS machine to get a spectrum from which the nitrogen content was estimated using a calibration equation developed by Angessa [12] and further improved by Towett [16]. The NIRSestimated nitrogen content data was then multiplied by 6.25 to obtain crude protein values.

\section{Data Analysis}

In order to detect the differences between treatments and across sites, data for crude protein content and iron concentration was subjected to analysis of variance using the SYSTAT 5.0 procedure general linear models [20]. If the least square mean values were significantly different at $\mathrm{P}<0.05$, a pair-wise comparison using Fisher's LSD test was performed. 


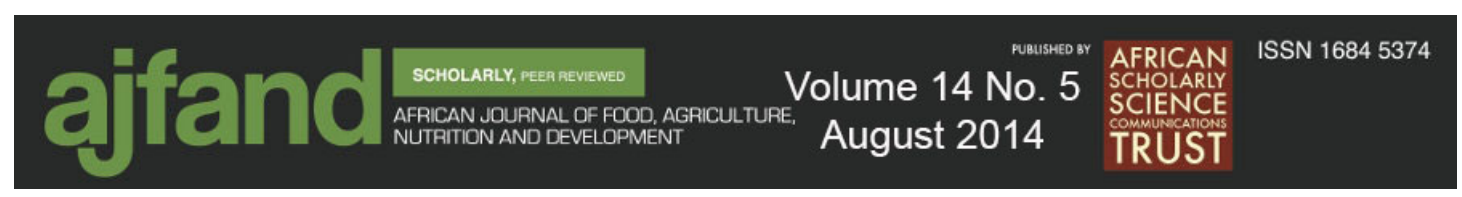

\section{RESULTS}

\section{Nutritional Quality of Cowpea Leaves}

The iron concentration was on average highest at Kogili village (387 $\mu \mathrm{g} / \mathrm{g})$ and lowest at Kikota village (176 $\mu \mathrm{g} / \mathrm{g})$. Mean iron values at Kikota village were, however, not significantly different $(\mathrm{p}=0.05)$ from those obtained at NaSARRI, Serere. Across treatments, there was no significant difference $(p=0.05)$ between the iron concentration values obtained for single varieties and their respective mixtures (The bars for single varieties and for all mixtures have the same letter indicating that they are not statistically significant).

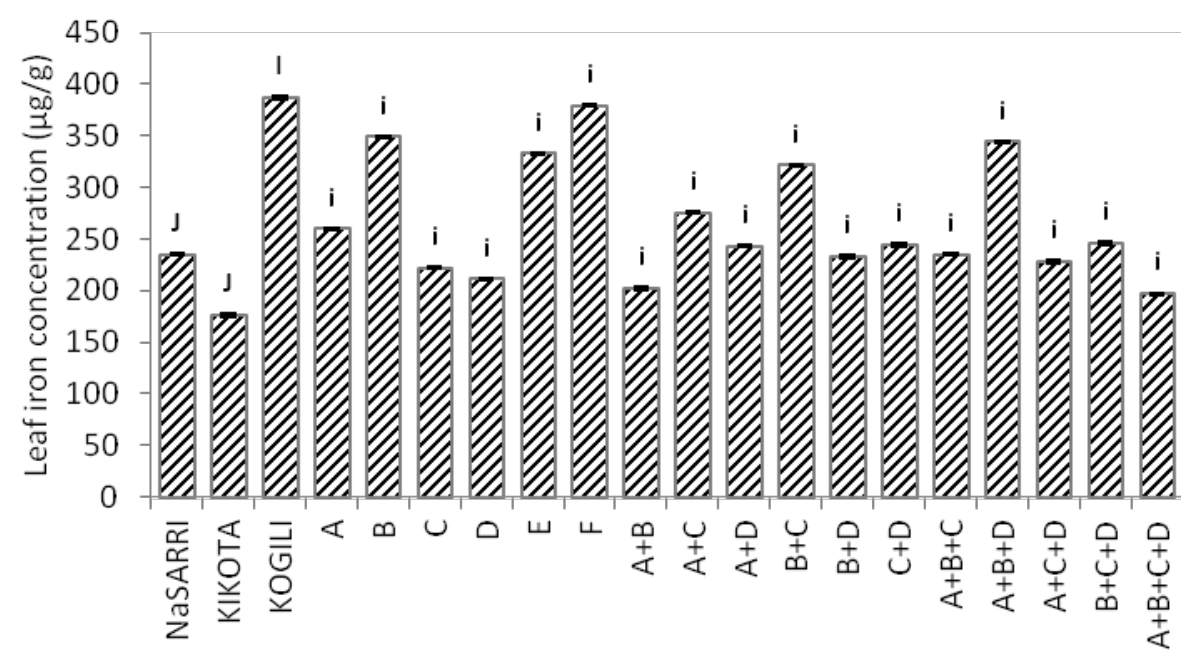

Sites and Treatments

Figure 2: Mean iron concentration of 153 open-air dried cowpea leaf samples from the second leaf harvest from the trials conducted at NaSARRI, Serere, Kikota and Kogili villages in Uganda during the first cropping season of 2008. Bars with the same letter (s) are not significantly different at $P<0.05$. Refer to Table 1 for variety names corresponding to ID A, B, $C, D, E$ and $F$. No significant interaction between treatments and environment was observed. Nevertheless, care must be taken with NIRSestimated iron concentration values, as only about $67 \%$ of the variation could be explained through spectral analysis.

The protein content of the open-air dried cowpea leaves from the second leaf harvest at the three trial sites was highest at NaSARRI, Serere and Kogili village (33\%) and lowest at Kikota village (27\%). The protein content varied significantly between treatments being highest in mixture A+D (34\%) and lowest in variety C (25\%). No significant interaction between treatments and environment was observed (Figure 3). Spectral analysis of NIRS-estimated protein content values accounted for nearly $90 \%$ of the variation. 

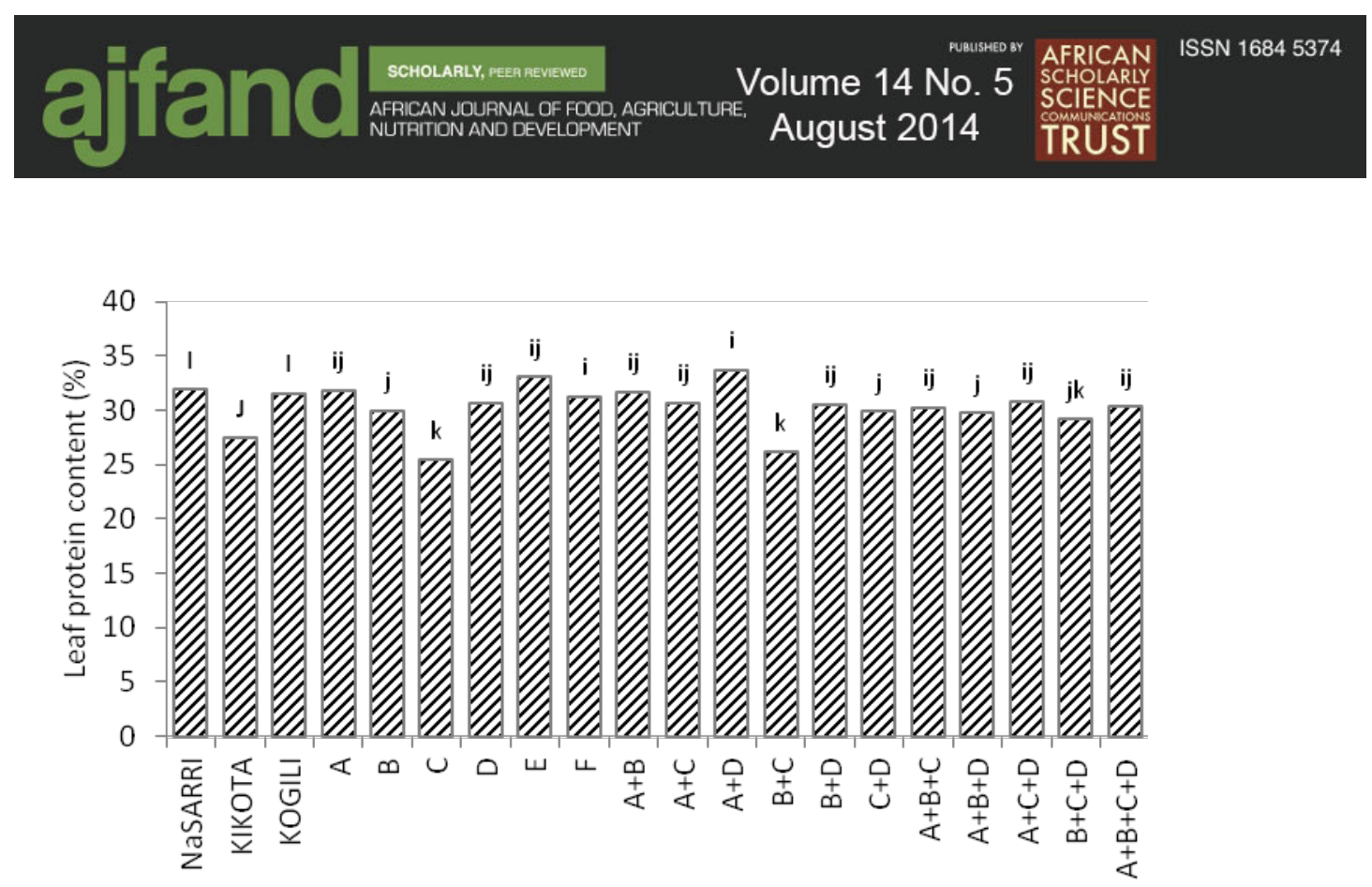

Sites and Treatments

Figure 3: Mean crude protein content of 153 open-air dried cowpea leaf samples from the second leaf harvest from the trials conducted at NaSARRI, Serere, Kikota and Kogili villages in Uganda during the first cropping season of 2008. Bars with the same letter (s) are not significantly different at $P<0.05$. Refer to Table 1 for variety names corresponding to ID $A, B$, $C, D, E$ and $F$

\section{DISCUSSION}

The concentration of iron $(176-387 \mu \mathrm{g} / \mathrm{g})$ obtained in this study is within the range of the values (157.4-575.0 $\mu \mathrm{g} / \mathrm{g}$ ) reported for the same varieties at NaSARRI [16]. There was a marked variation in the leaf protein content, with the two landraces $E$ and $\mathrm{F}$, being among the treatments showing the highest mean protein values. No literature on leaf protein content of the two Ugandan landraces was found and, therefore, no comparison could be made. However, for the four component varieties used in the mixtures, the leaf protein values obtained at the three sites of this study (27 - 32\%) compare well with those observed in Dodoma for the same varieties (31.4 to 33.9\%) [12]. The protein values realized in the current study are in the range of 29.4 to $34.3 \%$, which is similar to what other researchers observed although they were working with different varieties in sole-cropped cowpea [5, 11]. However, considerably higher cowpea leaf protein values of 35.0 to $43.1 \%$ [3] and $43.0 \%$ [18] have been previously reported. The leaf protein content, though influenced by environmental factors like soil fertility, is highly dependent on age of leaves, the amount of available assimilates and the ability of the individual variety to develop a symbiotic relationship with the nitrogen-fixing bacteria in the root nodules [18].

In addition to cowpea leaves being available as food (unlike seeds), throughout the cropping season, leaf protein content is higher than seed protein content. Protein values in the range of $29.4-33.1 \%$ for leaves and $24.7-25.7 \%$ for seeds have been observed [11]. The absence of phytic acid (storage form of phosphorous in seeds) in 


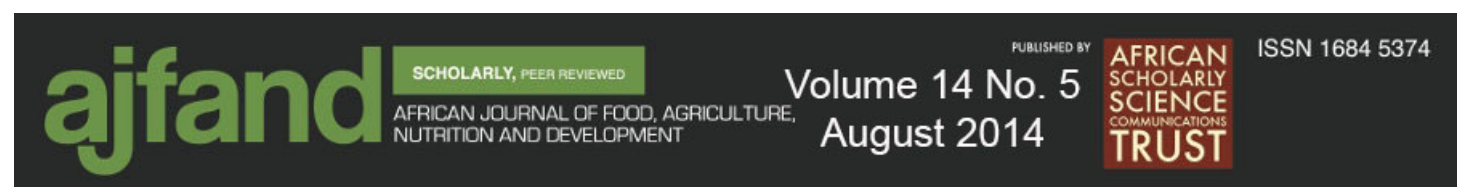

cowpea leaves increases the bioavailability of nutrients like calcium and iron, which are usually bound to phytic acid. Though not analyzed in this study, $\beta$-carotene values of young cowpea leaves collected from Tanzania and Uganda ranged from 4.1 to 30.5 mg/100 g dry matter [14]. A recent study in Kenya reported increased levels of blood haemoglobin level and $\beta$-carotene bioavailability after children consumed cowpea leaves [21].

These nutritional benefits, thus, make cowpea leaves an indispensable tool when targeting to improve the nutritional status of the resource-poor subsistence farmers especially in Uganda.

\section{CONCLUSION}

The traditional leaf-harvesting strategy provides leaves, which are an important source of iron (176 - $387 \mu \mathrm{g} / \mathrm{g}$ ) and protein (25 - 32\%) among resource-poor farmers. Compared to the tested varieties and their mixtures, iron concentration of landraces was not significantly higher. However, the protein content of two varieties (UG-CP-9 and IT 93K-2045-29) is relatively high for a plant source. These two Tanzanian varieties are recommended for release in Uganda. The leaf-harvesting strategy also provides leaves as food throughout the cropping season, and this contributes to household food security and fosters community relationships through free-sharing of cowpea leaves among community members. The nutritional quality of cowpea leaves was more influenced by the cultivars and not the environment.

\section{Acknowledgements}

We are grateful to the German Federal Ministry for Economic Cooperation and Development (BMZ) for funding this research. This work was carried out within the project 'Promotion of Neglected Indigenous Leafy and Legume Vegetable Crops for Nutritional Health in Eastern and Southern Africa' (ProNIVA) via the University of Götttingen, Germany. We thank Beatrice Ekesa (Bioversity International) for her comments on the manuscript. 


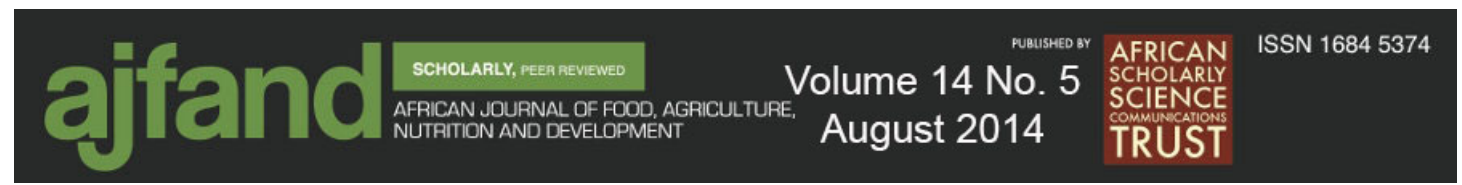

Table 1: Cowpea varieties used in the study of variety mixtures in Soroti and Kumi districts of Uganda during the first cropping season of 2008

\begin{tabular}{|c|c|c|c|c|}
\hline ID & Variety & Status & Original seed source & Current seed source \\
\hline A & UG-CP-9 (KOL 42) & Experimental line & Soroti , Uganda & AVRDC-RCA, Tanzania \\
\hline B & Dakawa & Cultivar & $\begin{array}{l}\text { Dakawa Reseach } \\
\text { Institute, Tanzania }\end{array}$ & AVRDC-RCA, Tanzania \\
\hline C & Ex-Iseke & Cultivar & Iseke village, Tanzania & AVRDC-RCA, Tanzania \\
\hline D & IT 93K-2045-29 & Experimental line & IITA, Nigeria & AVRDC-RCA, Tanzania \\
\hline $\mathrm{D}^{*}$ & ILRI 15742 & Research material & ILRI, Ethiopia & AVRDC-RCA, Tanzania \\
\hline $\mathrm{E}$ & Icirikukwai & Landrace & Soroti, Uganda & Serere market, Uganda \\
\hline $\mathrm{F}$ & Ebelat & Landrace & Soroti, Uganda & Serere market, Uganda \\
\hline
\end{tabular}

D* was used in place of $\mathrm{D}$ in the trial at Kikota village due to insufficient seed of D.

AVRDC-RCA = "The World Vegetable Center’s Regional Center for Africa”

Source: Okonya and Maass [19] 


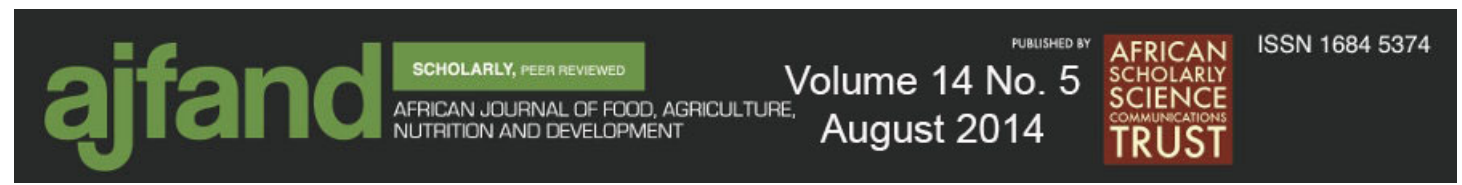

\section{REFERENCES}

1. Uganda Bureau of Statistics (UBOS) and ICF International Inc. Uganda Demographic and Health Survey 2011. Kampala, Uganda: UBOS and Calverton, Maryland: ICF International Inc., 2012.

2. Smith FI and P Eyzaguirre African leafy vegetables: their role in the World Health Organization's global fruit and vegetables initiative. African Journal of Food Agriculture Nutrition and Development 2007; 7(3): 631-632.

3. Nielsen SS, Ohler TA and TA Mitchell Cowpea leaves for human consumption: production, utilization, and nutrient composition. In: BB Singh, DR Mohan Raj, KE Dashiell and LEN Jackai (Eds). Advances in cowpea research. Co-publication of International Institute of Tropical Agriculture (IITA) and Japan International Center for Agricultural Sciences (JIRCAS), IITA, Ibadan, Nigeria, 1997.

4. Isubikalu P, Erbaugh JM, Semana AR and E Adipala Influence of farmer production goals on cowpea pest management in Eastern Uganda: Implications for developing IPM programmes. African Crop Science Journal 1999; 7 (4): 539-548.

5. Keding G, Weinberger $\mathbf{K}$, Swai $\mathbf{I}$ and $\mathbf{H}$ Mndiga Diversity, traits and use of traditional vegetables in Tanzania. Technical Bulletin No. 40. AVRDC - The World Vegetable Center, Shanhua, Taiwan, 2007.

6. Bittenbender HC, Barrett RP and BM Indire-Lavusa Beans and cowpeas as leaf vegetables and grain legumes. Occassional Monograph Series No.1, Bean/Cowpea C.R.S.P., Michigan State University, East Lansing, MI, USA, 1984.

7. Mamiro PS, Mbwaga AM, Mamiro DP, Mwanri AW and JL Kinabo Nutritional quality and utilization of local and improved cowpea varieties in some regions in Tanzania. African Journal of Food Agriculture Nutrition and Development 2011; 11(1): 4490-4506.

8. Kiremire BT, Musinguzi E1, Kikafunda JK and FB Lukwago Effects of vegetable drying techniques on nutrient content: a case study of south-western Uganda. African Journal of Food Agriculture Nutrition and Development 2010; 10(5): 2587-2600.

9. Ekesa BN, Walingo MK and MO Abukutsa-Onyango Accesibility to and consumption of indigenous vegetables and fruits by rural households in Matungu division, western Kenya. African Journal of Food Agriculture Nutrition and Development 2009; 9(8): 1725-1738 
10. Rubaihayo EB Conservation and use of traditional vegetables in Uganda. In: L Guarino (Ed). Traditional African Vegetables. Promoting the conservation and use of underutilized and neglected crops, Proceedings of the IPGRI International Workshop on Genetic Resources of Traditional Vegetables in Africa: Conservation and Use, 29-31 August 1995, ICRAF-HQ, Nairobi, Kenya. Institute of Plant Genetics and Crop Plant Research, Gatersleben / International Plant Genetic Resources Institute, Rome, Italy, 1997.

11. Nielsen SS, Osuala CI and WE Brandt Early leaf harvest reduces yield but not protein concentration of cowpea seeds. Horticultural science 1994; 29(6): 631-632.

12. Angessa TT Towards improved vegetable use and conservation of cowpea and lablab: Agronomic and participatory evaluation in Northern Tanzania and genetic diversity study. PhD thesis, Cuvillier Verlag, Göttingen, Germany, 2006.

13. Imungi JK and NN Potter Nutrient contents of raw and cooked cowpea leaves. Journal of Food Science 1983; 48: 1252-1254.

14. Kabululu MS, Ojiewo C, Oluoch $\mathbf{M}$ and BL Maass Cowpea cultivar mixtures for stable and optimal leaf and seed yields in a maize intercropping system. International Journal of Vegetable Science, 2013; 20(3). DOI: 10.1080/19315260.2013.813889.

15. Malidadi C Cowpea (Vigna unguiculata) for leafy vegetable use in Malawi: Agronomic evaluation onstation and onfarm. MSc Thesis at Georg-AugustUniversität, Göttingen, Germany, 2006.

16. Towett EK, Alex M, Shepherd KD, Polreich S, Aynekulu E, and BL Maass Applicability of near-infrared reflectance spectroscopy (NIRS) for determination of crude protein content in cowpea (Vigna unguiculata) leaves. Food Science \& Nutrition 2013; 1(1): 45-53.

17. Weinberger $\mathbf{K}$ and $\mathbf{J}$ Msuya Indigenous vegetables in Tanzania significance and prospects. Technical Bulletin No. 31. AVRDC - The World Vegetable Center, Shanhua, Taiwan, 2004.

18. Ono K, Terashima I and A Watanabe Interaction between nitrogen of plant and nitrogen content in the old leaves. Plant Cell Physiology 1996; 37 (8): 1083-1089.

19. Okonya JS and BL Maass Potential of Cowpea Variety Mixtures to Increase Yield Stability in Subsistence Agriculture: Preliminary Results. International Journal of Agronomy 2014; 2014

20. SYSTAT 5.0 SYSTAT for Windows. SYSTAT Inc. Chicago, IL, USA, 1994. 


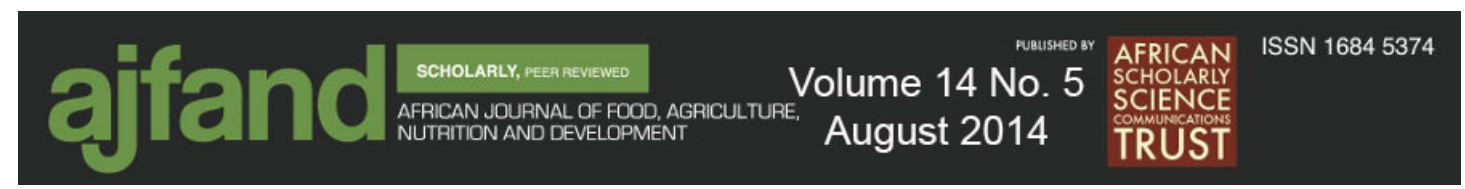

21. Nawiri M P, Nyambaka $\mathbf{H}$ and JI Murungi. Sun-dried cowpeas and amaranth leaves recipe improves $\beta$-carotene and retinol levels in serum and haemoglobin concentration among preschool children. European journal of nutrition 2013; 52(2):583-589. 